IRA-International Journal of Applied Sciences ISSN 2455-4499; Vol.07, Issue 02 (2017)

Institute of Research Advances

Pg. no. 95-102

https://research-advances.org/index.php/IRAJAS

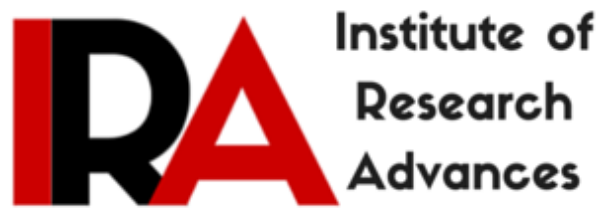

\title{
Area Under the Curve Spectrophotometric Method for Determination of Irbesatran in Pharmaceutical Formulation
}

\author{
S. Alexandar ${ }^{1}$, A. Santhanam ${ }^{2}$, C. Sandhu ${ }^{3}$, C. Sanjaykanth ${ }^{4}$, S. Sandhya ${ }^{5}$, G. \\ Santhosh Kumar ${ }^{6}$ and B. Jaykar ${ }^{7}$
}

1,2,3,4,5,6,7 Department of Pharmaceutical Analysis, Vinayaka Mission's College of Pharmacy, Salem -636008, Tamilnadu, India.

Type of Review: Peer Reviewed.

DOI: http://dx.doi.org/10.21013/jas.v7.n2.p5

\section{How to cite this paper:}

Alexandar, S., Santhanam, A., Sandhu, C., Sanjaykanth, C., Sandhya, S., Santhosh Kumar, G., Jaykar , B. (2017). Area Under the Curve Spectrophotometric Method for Determination of Irbesatran in Pharmaceutical Formulation. IRA-International Journal of Applied Sciences (ISSN 2455-4499), 7(2), 42-51. doi:http://dx.doi.org/10.21013/jas.v7.n2.p5

(C) Institute of Research Advances

\section{(c) BY-NC}

This work is licensed under a Creative Commons Attribution-Non Commercial 4.0 International License subject to proper citation to the publication source of the work.

Disclaimer: The scholarly papers as reviewed and published by the Institute of Research Advances (IRA) are the views and opinions of their respective authors and are not the views or opinions of the IRA. The IRA disclaims of any harm or loss caused due to the published content to any party. 


\section{ABSTRACT}

This study presents new spectrophotometric method for the determination of Irbesartan. So far, no Area under Curve Spectrophotometric method has been reported for the estimation of Irbesartan from pharmaceutical dosage form. This paper deals with validation and development of a method by Area Under Curve for the assay of Irbesartan from pharmaceutical dosage forms. The principle for AUC curve method is "the area under two points on the mixture spectra is directly proportional to the concentration of the component of interest". The area selected between 203 to $211 \mathrm{~nm}$ for determination of Irbesartan. The drug follows Beer-Lambert's law over the concentration range of 5 $25 \mu \mathrm{g} / \mathrm{ml}$ for Irbesartan. In accuracy study the \% recovery of Irbesartan in bulk drug samples was ranged 96.45-93.84\%, which indicates that the method was accurate. Validation of the proposed method was carried out for its accuracy, precision, and specificity according to ICH guidelines. The proposed methods can be successfully applied in routine work for the determination of Tigecycline in its pharmaceutical dosage form.

Key Words : Irbesatran, UV Method, Area under curve

\section{Introduction}

Irbesartan is an angiotensin II receptor antagonist used in the management of hypertension including treatment of renal disease in hypertensive type II diabetic patients. It possesses acidic tetrazole system and biphenyl system, does not have acidic side chain and even so it has good affinity for angiotensin II receptor because of hydrogen bonding with the carbonyl moiety of amide system [2]. Irbesartan is a non-peptide compound, chemically described as a 2-butyl-3-[p-(o-1H-tetrazol-5phenyl)benzyl]-1 ,3-diazaspiro[4.4]non-1 -en-4-one. Its empirical formula is $\mathrm{C} 25 \mathrm{H} 28 \mathrm{~N} 6 \mathrm{O}$, and the structural formula is shown in Fig.1. Irbesartan is a white to offwhite crystalline powder with a molecular weight of 428.5. Irbesartan is slightly soluble in alcohol and methylene chloride and practically insoluble in water[3]. Several methods were developed for the estimation of aceclofenac by HPLC, visible and UV spectroscopy [4-17] individually or in combination. In the present research paper, attempt made to develop a new spectrophotometric method for the determination of Irbesartan. So far, no Area under Curve Spectrophotometric method has been reported for the estimation of Irbesartan from pharmaceutical dosage form. This paper deals with validation and development of a method by Area under Curve for the assay of Irbesartan from pharmaceutical dosage forms.

\section{Materials and Methods}

Irbesartan was a gift sample by orchid chemicals, Chennai, India was used without further purification. All chemicals and reagents used were of analytical grade and were purchased from Merck Chemicals, India.

\section{Instrumentation}

For all the spectrophotometric methods, Shimadzu model 1700 double beam UV-VIS spectrophotometer with spectral bandwidth of $1.8 \mathrm{~nm}$, wavelength accuracy of $2 \mathrm{~nm}$ and a pair of $1 \mathrm{~cm}$ matched quartz cells of $10 \mathrm{~mm}$ optical path length was used.

\section{Experiment \\ Standard preparation of Irbesartan}

Accurately weighed $100 \mathrm{mg}$ of Irbesartan and transferred into $100 \mathrm{~mL}$ clean, dry, volumetric flask, add $50 \mathrm{~mL}$ of methanol, sonicated for $5 \mathrm{~min}$, dilute to volume with methanol and filtered through $0.45 \mu \mathrm{m}$ membrane filter. Take $2.5 \mathrm{~mL}$ from above solution and make up to $100 \mathrm{~mL}$ with methanol $(25 \mu \mathrm{g} / \mathrm{mL})$. The above solution was scanned from $200-400 \mathrm{~nm}$. 


\section{Analysis of marketed formulation}

Twenty tablets were weighed and average weight was calculated. These tablets were crushed and powdered in a glass mortar. The tablet powder equivalent to $150 \mathrm{mg}$ of Irbesartan was accurately weighed, transferred to a $100 \mathrm{~mL}$ of volumetric flask and diluted up to mark with methanol. Sonicated for $15 \mathrm{~min}$ and filtered through $0.45 \mu \mathrm{m}$ membrane filter. Further diluted to obtain a concentration of $50 \mu \mathrm{g} / \mathrm{ml}$.

\section{VALIDATION PARAMETERS}

Linearity

Preparation of stock solution

Standard preparation of Irbesartan

Accurately weighed $100 \mathrm{mg}$ of Irbesartan and transferred into $100 \mathrm{~mL}$ clean, dry, volumetric flask, add $50 \mathrm{~mL}$ of methanol, sonicated for $5 \mathrm{~min}$, dilute to volume with methanol and filtered through $0.45 \mu \mathrm{m}$ membrane filter. Take $5 \mathrm{~mL}$ from above solution and make up to $100 \mathrm{~mL}$ with methanol. From this stock solution $5-25 \mu \mathrm{g} / \mathrm{ml}$ solution was prepared.

\section{Limit of Detection:}

The limit of detection (LOD) is defined as the lowest concentration of the analyte in a sample that can be detected, though not necessarily quantified. It was a limit test that specifies whether or not an analyte is above or below a certain value. It was expressed in a concentration at a specified signal-to-noise ratio, usually 3:1 ratio.

\section{limit of Quantization}

$$
\mathrm{LOD}=3 * \sigma / \text { slope }
$$

The limit of quantification (LOQ) defined as the lowest concentration of an analyte in a sample that can be determined with acceptable precision and accuracy under the stated operational conditions of the method.

\section{Robustness}

$$
\mathrm{LOQ}=10 * \sigma / \text { slope }
$$

As part of the robustness, deliberate change in the flow rate and mobile phase composition was made to evaluate the impact on the method. The mixed standard solution is injected in two replicate and $\%$ RSD was calculated.

\section{RESULTS AND DISCUSSIONS}

UV spectroscopy method was established for the quantitative analysis of Irbesartan in bulk and formulation. Thus the proposed method is appropriate for the simultaneous determination of Irbesartan can be useful for the routine analysis of the drug.

\section{UV-SPECROPHOTOMETRIC METHOD DEVELOPMENT Optimized Method}

The diluents used is methanol AUC Method( Area Under Curve Method)

Spectra of Irbesartan 


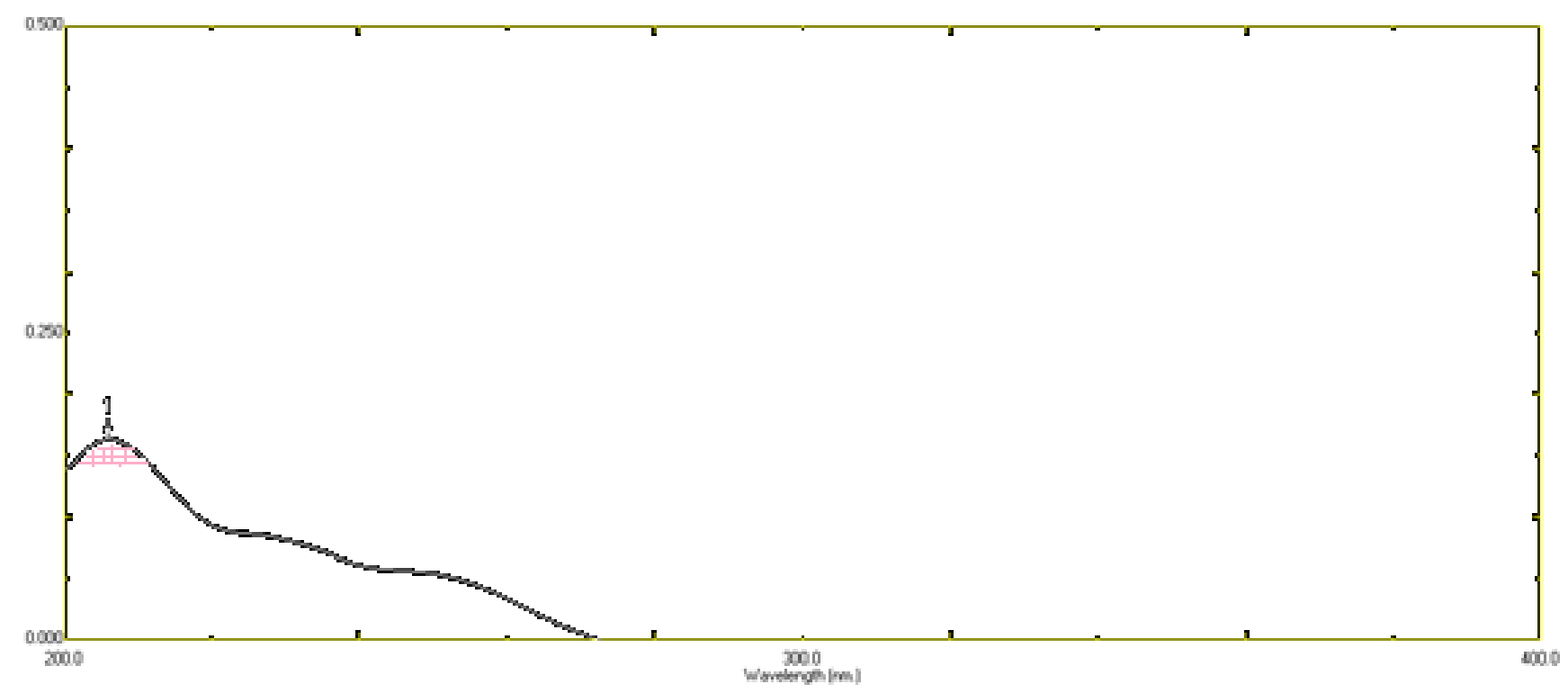

The above spectra represents the AUC of Irbesartan from 203-211nm selected as the two a sampling wavelength.

\section{VALIDATION PARAMETERS}

\section{LINEARITY}

Linearity study of Irbesartan was performed by preparing different concentrations of solution $5 \mu \mathrm{g} / \mathrm{mL}, 10 \mu \mathrm{g} / \mathrm{mL}, 15 \mu \mathrm{g} / \mathrm{mL}, 20 \mu \mathrm{g} / \mathrm{mL}$ and $25 \mu \mathrm{g} / \mathrm{mL}$.

\begin{tabular}{|c|c|c|}
\hline Concentration $(\mu \mathrm{g} / \mathrm{mL})$ & Absorbance of Irbesartan & $\begin{array}{c}\text { Statistical Analysis of } \\
\text { Irbesartan }\end{array}$ \\
\hline 5 & 0.2858 & \multirow{5}{*}{$\begin{array}{l}\text { Slope }=0.063 \\
\text { Correlation } \\
\text { coefficient }=0.998\end{array}$} \\
\hline 10 & 0.5845 & \\
\hline 15 & 0.9373 & \\
\hline 20 & 1.2428 & \\
\hline 25 & 1.5908 & \\
\hline
\end{tabular}




\section{Linearity of Irbesartan}

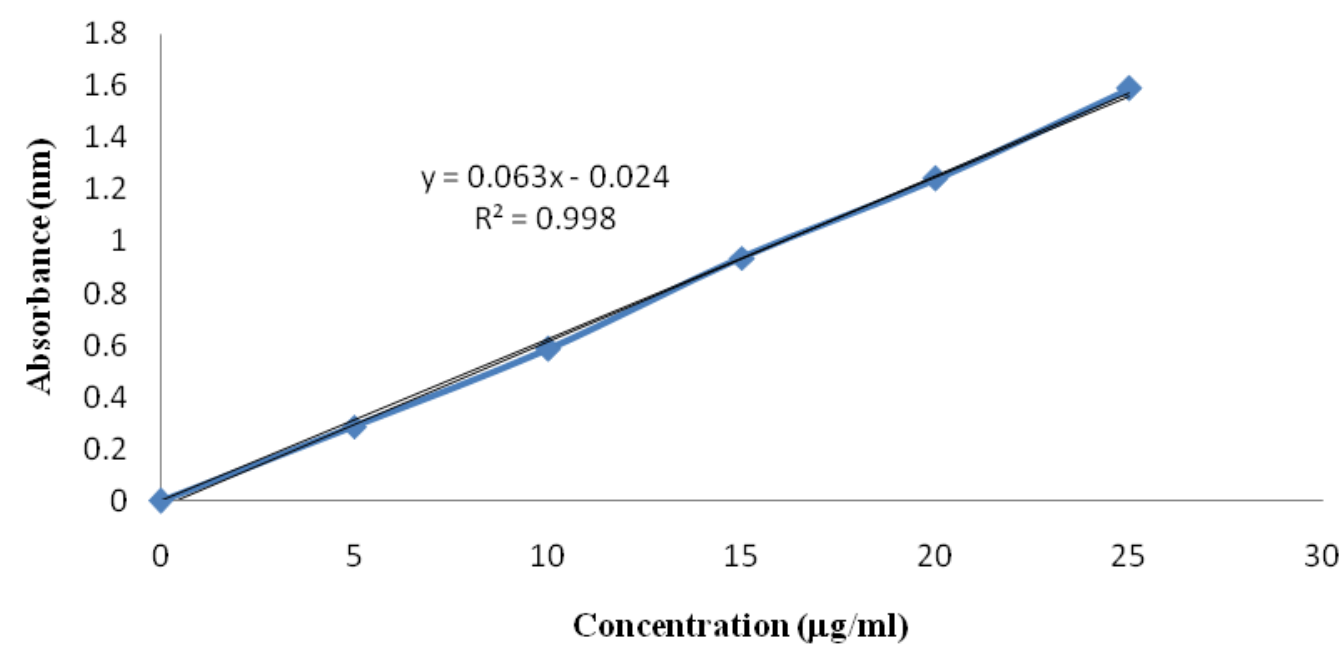

\section{Result}

The drug obeys beer lambert's law. The calibration plot was observed it is linear in the range of $5-25 \mu \mathrm{g} / \mathrm{mL}$ for Irbesartan. The correlation co efficient was found to be 0.998 .

\section{Precision}

Intraday Precision Study

Method precision study of Irbesartan was performed by single analyst in different hours within in a day at the concentration of $25 \mu \mathrm{g} / \mathrm{mL}$.

\begin{tabular}{|c|c|}
\hline S.No & Absorbance \\
\hline 1 & 1.592 \\
\hline 2 & 1.589 \\
\hline 3 & 1.562 \\
\hline 4 & 1.515 \\
\hline 5 & 1.573 \\
\hline 6 & 1.536 \\
\hline Mean & 1.561 \\
\hline SD & 0.0277 \\
\hline \%RD & 1.77 \\
\hline
\end{tabular}

\section{Result}

The $\%$ RSD should not be more than $2 \%$. As per ICH guidelines in the present study, the $\%$ RSD for Irbesartan was found to be $1.77 \%$. The $\%$ RSD value indicates a good degree of precision within the specified range. This indicates the method is precise.

Interday Precision Study: (Ruggedness) $50 \mu \mathrm{g} / \mathrm{mL}$.

System precision of Irbesartan was performed in a three different days at the concentration of 


\begin{tabular}{|c|c|c|c|}
\hline S.No & Day 1 & Day 2 & Day 3 \\
\hline 1 & 1.523 & 1.492 & 1.587 \\
\hline 2 & 1.535 & 1.519 & 1.548 \\
\hline 3 & 1.518 & 1.552 & 1.515 \\
\hline 4 & 1.596 & 1.545 & 1.565 \\
\hline 5 & 1.513 & 1.573 & 1.582 \\
\hline 6 & 1.526 & 1.513 & 1.565 \\
\hline Mean & 1.535 & 1.532 & 0.027 \\
\hline SD & 0.028 & 0.027 & 1.72 \\
\hline \%RSD & 1.82 & 1.76 & \\
\hline
\end{tabular}

\section{Result}

The \%RSD should not be more than $2 \%$. As per ICH guidelines in the present study, the \% RSD for Irbesartan was found to be $1.82 \%, 1.76 \%$ and $1.72 \%$.

\section{Accuracy}

Accuracy study of Irbesartan was performed using methanol as solvent.

\begin{tabular}{|l|l|l|c|c|c|c|}
\hline Level & $\begin{array}{l}\text { Amount } \\
\text { Present } \\
(\mu \mathrm{g} / \mathrm{mL})\end{array}$ & $\begin{array}{l}\text { Amount } \\
\text { Added } \\
(\mu \mathrm{g} / \mathrm{mL})\end{array}$ & $\begin{array}{c}\text { Absorbance } \\
\text { of Irbesartan } \\
(\mathrm{n}=3)\end{array}$ & $\begin{array}{c}\text { Amount } \\
\text { Recovery }\end{array}$ & $\begin{array}{c}\text { Amount } \\
\text { Recovery }\end{array}$ & $\% \mathrm{RSD}$ \\
\hline $25 \%$ & 100 & 5 & 0.2912 & 24.34 & 96.45 & 0.010 \\
\hline $50 \%$ & 100 & 10 & 0.5876 & 49.98 & 97.90 & 0.007 \\
\hline $75 \%$ & 100 & 15 & 0.9367 & 74.76 & 93.84 & 0.003 \\
\hline
\end{tabular}

\section{Result:}

The percentage recovery of Irbesartan at $25 \%, 50 \%, 100 \%$ was found to be $96.45 \%, 97.50 \%$, $93.84 \%$.

\section{Limit of Detection and Quantitation:}

LOD and LOQ of Irbesartan were determined by calibration curve method.

\begin{tabular}{|c|c|c|}
\hline S.No & Concentration $(\mu \mathrm{g} / \mathrm{mL})$ & Absorbance of Irbesartan \\
\hline 1 & 5 & 0.2858 \\
\hline 2 & 10 & 0.5845 \\
\hline 3 & 15 & 0.9373 \\
\hline 4 & 20 & 1.2428 \\
\hline 5 & 25 & 1.5908 \\
\hline \multicolumn{2}{r}{} & 0.5978 \\
\hline \multicolumn{2}{r}{ SD $(\sigma)$} & 0.063 \\
\hline
\end{tabular}




\begin{tabular}{|c|c|}
\hline LOD $(3 \times \sigma /$ Slope $)$ & $28.46 \mu \mathrm{g} / \mathrm{mL}$ \\
\hline LOQ $(10 \times \sigma /$ Slope $)$ & $76.45 \mu \mathrm{g} / \mathrm{mL}$ \\
\hline
\end{tabular}

\section{Result:}

LOD and LOQ determination is based on the standard deviation of the response and slope. LOD and LOQ of Irbesartan were found to be $28.46 \mu \mathrm{g} / \mathrm{ml}$ and $76.45 \mu \mathrm{g} / \mathrm{ml}$ respectively.

\section{SUMMARY AND CONCLUSIONS}

In the present work, we have developed a newer, simple, accurate and cost effective area under curve Spectrophotometric method for the effective quantitative determination of Irbesartan in bulk and pharmaceutical dosage form without the interferences of other constituent in the formulations.

\section{Area under Curve Method}

- Detection of $\lambda$ max of Irbesartan was found to be 203-211 $\mathrm{nm}$. The proposed method was validated as per ICH guidelines. The method validated data showing satisfactory results for method validation tested.

- The method was found to be linear in the concentration ranges from 5-25 $\mu \mathrm{g} / \mathrm{mL}$ for Irbesartan with correlation coefficient 0.998 .

- In precision study it was found that \%RSD is less than $2 \%$ which indicated that the proposed method has good reproducibility.

- In accuracy study the \% recovery of Irbesartan in bulk drug samples was ranged 96.45-93.84\%, which indicates that the method was accurate.

- LOD and LOQ, the limit of detection (LOD) was found to be $28.46 \mu \mathrm{g} / \mathrm{ml}$ and Limit of quantitation $76.45 \mu \mathrm{g} / \mathrm{ml}$.

\section{Conclusion}

The UV spectrophotometric AUC method developed for determination of Irbesartan was based on different analytical techniques, UV-Spectrophotometric, AUC method. The method was validated and found to be simple, sensitive, accurate, and precise in compliance to the limits stated in the ICH guidelines. Hence, we conclude that the method can be used successfully for routine analysis of pharmaceutical dosage forms containing Irbesartan. The proposed spectrophotometric method will not replace the presently known methods available for the analysis of Irbesartan. However, it can serve as an alternative where advanced instruments (e.g. HPLC) are not available for routine analysis.

\section{References}

1. Aringül Dal, Semakoyutürk A.G. Dal and S. Koyutürk Hacettepe J. Biol. And Chem, 2015, 43 (3) 145-152.

2. B. Raja, Potru Himasri, Bantu Ramadevi Int. Res J Pharm.App Sci, 2012, 2(3), 29-38.

3. G.Kumara Swamy, J.M.R.Kumar , J.V.L.N.Seshagiri Rao, World Journal Of Pharmacy And Pharmaceutical Sciences, 2014, 3(11), 996-1007.

4. K. Tirumala Rao, L.Vaikunta Rao And V. V. Krishna Mohan Kandepi Indian J Pharm Sci, 2016, 78(2), 252-258.

5. Kumaraswamy Gandla, R. Suthakaran, Pravalika Kondoji, Am. J. Pharm Health Res, 2014, 2(1), 547-552.

6. Lakshmi Sivasubramanian and Ks. Lakshmi, International Journal of Research in Pharmacy and Chemistry, 2014, 4(2), 373-380.

7. Martindale, The Complete Drug Reference, 34th Edn, pharmaceutical press, p. 940, 
8. Mazharuddin M. Shaikh, Stavan Master and Abrar M. Chaudhary International Bulletin of Drug Research. 2014, 4(7), 1-15.

9. P Palatini. The Journal of Clinical Hypertension., 2005, 7, 96-101.

10. P. Prabhu, M. Muralidhar International Journal of Pharmaceutical Sciences and Drug Research, 2014, 6(2), 145-153.

11. Pramod L. Ingale, Sampada D. Dalvi1, Abhijitr. Salunkhe, Indo American Journal of Pharmaceutical Research, 2016, 6 (4), 5242-5247.

12. R. Ramesh Raju, N.Bujji Babu, Pharmacophore, 2011, 2 (2), 145-149.

13. Ramesh Bhukya, Elizabeth Y, Dhanalaxmi K, D. Nagarjuna Reddy Int J Pharm 2013, 3(3), 521526.

14. S.V.S.G.B.Prasad, Savithiri Shivakumar, T.Sudhir, R.Mital, G.Devala Rao International Journal of Pharmacy and Pharmaceutical Sciences, 2009, 1(1), 206-210.

15. T. M. Kalyankar, S. J. Wadher, S. S. Pekamwar And N.G. Doiphode Int. .Journal of Pharm Tech Research, 2014, 6(1), 330-336.

16. Tamer Awad Ali1, Gehad G. Mohamed, Ali A. Aglan, Fakiha El-Taib Heakal Chin J Anal Chem, 2016, 44(1), 1601-1608.(2005).

17. The Merck Index, 13th Edn., Merck Research Laboratories, Merck \& Co., White House Station, NJ, USA, p. 914, (2001). 